\title{
Diagnosing and prognosticating the quality movement - a review on the 25 years quality literature (1987-2011)
}

Su Mi Dahlgaard-Park, Chi-Kuang Chen, Jiun-Yi Jang and Jens Jörn Dahlgaard

\author{
Linköping University Post Print
}

\section{Tweet}

N.B.: When citing this work, cite the original article.

This is an electronic version of an article published in:

Su Mi Dahlgaard-Park, Chi-Kuang Chen, Jiun-Yi Jang and Jens Jörn Dahlgaard, Diagnosing and prognosticating the quality movement - a review on the 25 years quality literature (19872011), 2013, Total Quality Management and Business Excellence, (24), 1-2, 1-18.

Total Quality Management and Business Excellence is available online at informaworldTM: http://dx.doi.org/10.1080/14783363.2012.756749

Copyright: Taylor \& Francis (Routledge): SSH Titles http://www.routledge.com/

Postprint available at: Linköping University Electronic Press http://urn.kb.se/resolve?urn=urn:nbn:se:liu:diva-102990 


\title{
Diagnosing and Prognosticating the Quality Movement - a Review on the 25 Years Quality Literature (1987-2011)
}

\author{
Su Mi Dahlgaard-Park* \\ Professor, Department of Service Management \\ Lund University, Sweden. Sumi.park@msm.lu.se \\ Chi-Kuang Chen \\ Professor, Department of Industrial Engineering \& Management, \\ Yuan Ze University, 135 Yuan-Tung Road, Chung-Li 320, Taiwan, ROC \\ ieckchen@saturn.yzu.edu.tw \\ Jiun-Yi Jang \\ Ph.D Student, Department of Industrial Engineering \& Management, \\ Yuan Ze University, Taiwan, \\ Jens J. Dahlgaard \\ Professor, Department of Management and Engineering \\ Linköping University, Sweden \\ *Corresponding author: Email: sumi.park@msm.lu.se
}

\section{Abstract}

The purpose of this article is to create a snapshot of 25 years quality movement. The creation process of the snapshot as well as the result of the study aims to help in diagnosing the current status of Quality Management and further contribute in understanding and shaping its future direction. For this purpose all published articles during the last 25 years period (1987-2011) under the subject of TQM, Business Excellence, quality tools, techniques as well as core values/ principles have been collected through ABI/INFORM complete periodical database. The collected data were analyzed and reflected in order to show the current status, evolution trends of the past and the predicted future directions. The results show that the total number of articles under the subject of TQM has been decreasing after having reached its peak in 1995. However, papers focusing on techniques and tools within the quality management framework in terms of Lean, JIT/TPS, Benchmarking, and Six Sigma Quality have been increasing. In addition papers focusing on core values/ key principles needed to build a quality culture in terms of leadership, people based management, continuous improvements, management based on facts, and focus on the customer have been slightly increasing during the last decade. The findings indicate that quality management is now in a more mature stage where focuses have shifted from an initial focus on TQM to tools, techniques and core values which are needed 
for building a quality and business excellence culture. Based on the evolution it is concluded that TQM can be understood as a management innovation, if not a management revolution.

Key words: Quality movement, Business Excellence, Total Quality Management, Quality tools \& techniques, Lean, Six Sigma, quality culture, future trend

\section{INTRODUCTION}

Quality Management (QM) and in particular Total Quality Management (TQM) has been one of the most dominating and pervasive managerial approaches all over the world during the last three decades. In particular, from the late 1980s to the middle of the 1990s, the term TQM became more and more frequently used in the management literature and magazines as well as in the business world. However, during the first 10 years of the new millennium the term TQM seems to have lost its attractiveness in the industrialised parts of the world and instead new terms like Business Excellence, Organizational Excellence, Six Sigma Quality, and Lean seem to have overtaken the position of TQM even though the contents of these new terms are within the framework of QM (Dahlgaard-Park, 2011).

Due to the sudden popularity of new management topics or theories related to TQM a new research area has emerged where researchers are investigating the generic lifecycle of management techniques and the phenomenon of management fads and fashions (Abrahamson, 1991 \& 1996; Scarbrough et al., 2005). After a relatively short, temporary craze of intense interest on TQM the approach was questioned whether it was a management fad (Wilkinson and Wilmott, 1996; Van Der Wiele et al., 2000).

However the majority of quality professionals know well and hence generally agree that TQM is one of several phases in the 80 years evolution of modern quality management initiated by Shewhart in the 1930s. In line with opinions held by the majority of quality professionals Dahlgaard-Park $(2006 ; 2011)$ updated and reflected on the quality evolution and documented the 'travel' of the QM approach from US to Japan during the 1950s and from Japan to the industrialised world during the 1980s and 1990s. The 'travel' of the QM approach from West to East and from East to West was at the same time the 'becoming/ evolving' process of TQM.

While 'traveling' from US to Japan and from Japan to the West, QM evolved from a narrow tool and technique oriented statistical Quality Control approach to the synthetic managerial philosophy called TQM. Generally the term TQM refers to a 
holistic management system involving the three sub-managerial issues of efficiency, quality of working life, and effectiveness. Efficiency issues are rooted to the traditions of Process Engineering, Operations Management, Operations Research, and Statistical Process Control. The key concepts here are pursuing efficiency and continuous improvements. Achieving quality of working life and synergy is through teamwork, motivation and empowerment. This area is related to the Human Relations and the Human Resource School of Management. Achieving effectiveness is related to the strategic concern and is related to issues of goals, survival, profits, and market share. Hence quest of effectiveness is related to the Strategic Management school. The key concepts here are strategy, vision, mission and benchmarking (see Costin, 1994; Dahlgaard-Park, 1999; 2011).

The last two sub schools, in terms of the people dimension and strategic issues (e.g. HRM and Strategic Management), have been included into the framework of TQM as a result of the quality evolution which took place in Japan. The Japanese way of interpreting, understanding, practicing and further developing the idea of QM during three decades (1950-1980) resulted in the expansion of the quality framework and gave birth to 'Company Wide Quality Control' (CWQC). The Japanese way of practicing QM in terms of CWQC was not only to use statistical quality control tools, but they also involved HRM as well as strategic issues with clear long term as well as short term goals and visions. TQM became a holistic managerial system containing tools and techniques as well as elements of HRM and Strategic Management when the Japanese term CWQC was translated into TQM in the late 1980s. Seen from an evolution perspective TQM can be understood as a child born from a marriage between west and east. QM in term of TQM became thus not only the first management approach which embraced both western and eastern ways of thinking and practices, but it also became the first comprehensive management approach which covered the three key areas of management Process/Operation Management, Human Resource Management and Strategic Management. Hence TQM can be understood as a management innovation, if not a management revolution (Dahlgaard-Park, 1999 \& 2011). This conclusion or observation is also based on what Wruck \& Jensen (1994) concluded: 'TQM is a science and art of organization's management, the practice of value and strength, while creating sustainable development, excellence and success of an organization and society'.

It is not easy to measure the precise impact of TQM wave. However seen from a managerial evolution view it is not misleading to say that the TQM has opened a new era which are represented by Organizational Culture Reform Movements (Shafritz \& 
Ott, 2001), or The Culture-Excellence approach (Burns, 2000), Learning Organization (Senge, 1990) and the Personal Development (Covey, 1989).

Containing the three managerial approaches of Process Management, HRM and Strategic Management, TQM became a comprehensive management approach which includes multiple layers and elements/components within its umbrella. One of the negative consequences of the comprehensiveness and the multiple layers as well as the multiple subgroups of layers which gradually have been absorbed under the TQM Umbrella is the difficulty to grasp and understand the QM phenomenon. The more comprehensive QM becomes the more difficult it will be to grasp it, and hence it may create more confusions among various stakeholders such as top management, middle management as well as employees.

Based on these lines of thought the purpose of this article is to create a snapshot of the last 25 years' research on QM. The snapshot will be created by investigating and analysing published research papers within QM from 1987 to 2011. The snapshot will include 1) the current status quo of $\mathrm{QM}$ in terms of the total number of published research papers within selected key quality areas, 2) reflections on the longitudinal development and the evolution pattern/ trends of the past 25 years, and 3) predicting some possible future direction(s) of QM.

It is our hope that the creation process of the snapshot as well as the result of the study will help the readers in diagnosing the current status of QM and further contribute in understanding and shaping its future direction. In line with Abrahamson (1996) we believe that management scholars should not only study the trends and popularity of management techniques but they should also be actively engaged in shaping those trends.

\section{Quality Management Taxonomy}

As mentioned in the previous section QM came to embrace many layers and subcategories under the TQM umbrella. Due to the 'constantly transforming' character of QM (Dahlgaard-Park, 2006), confusions and hence frustrations have also been attached to the QM phenomenon. The confusions have been related either to conceptual aspects or to the implementation/ practical aspects of QM.

Some of the frequently discussed problems related to conceptual aspects are 1) difficulty to define what is TQM, 2) how to categorise various layers and subgroups, 3) what to include and what to exclude under the TQM umbrella, 4) what terms are 
suitable to adopt in the categorization attempt, 5) what are the relationships between TQM, Business Excellence, Lean and Six Sigma, and 6) is TQM unique?

The problem issues related to implementation aspects are 1) does TQM work?, and 2) if it works, does it work in any situation?,3) what is the best implementation strategy?, 4) what are the critical success factors?, and 5) how to choose the best roadmap and tools? There have been numerous discussions on those issues and many researchers have attempted to create a TQM taxonomy in order to clarify some of the above mentioned issues (Dahlgaard-Park, 1999 \& 2011; Hellsten \& Klefsjö, 2000).

Because TQM has become comprehensive, having multiple characteristics and levels/ dimensions, various terminologies have been used when referring to TQM and its various components. A framework, a philosophy, a system and a management approach are some frequently used alternative terminologies.

A problem is that the various quality or excellence models/ frameworks such as the EFQM Excellence Model, the Malcolm Baldrige National Quality Award model, the Deming Prize as well as Lean, Six Sigma, and JIT, where the latter three are more or less belonging to roadmaps and techniques, are all called as frameworks, approaches, or systems. In the same manner, the widely identified core values in TQM in terms of leadership, customer focus, management by fact, people based management, and continuous improvement have been referred inconsistently with various terms such as core values, concepts, principles, building blocks, and cornerstones (Dahlgaard et al 1992 \& 1994; Bergman \& Klefsjö, 1994; Oakland, 1999; Dahlgaard-Park, 1999; 2006-a; 2011).

One of the early attempts of defining Total Quality was presented by Dean and Bowen (1994). They viewed TQ as a management philosophy or an approach that can be characterised by its principles, practices and techniques. Hellsten \& Klefsjö (2000) suggested an idea that TQM should be considered as a management system containing the three interdependent components of 1) core values, 2) tools and, 3) techniques. The core values are related to norms and value system which become the foundation in building an organizational culture, as values guide and shape the attitude and behaviours and thereby guiding organizational members in their daily activities (Dahlgaard-Park, 2012). Techniques and tools help organizations in realising the values. Techniques can be a collection of several tools and thereby can have a more comprehensive character than tools. As such, the boundary between tools and techniques can be ambiguous. Hence we have in our research integrated tools and 
techniques in the same category, because they possess essentially the same attribute that is means/instruments/methods/know-how for achieving goals (e.g. excellence in quality). In order to achieve the objective of our study - drawing a snapshot of Quality management - we have adopted the following three categories:

1. Models or frameworks e.g. TQM \& Organizational Excellence,

2. Management Tools and Techniques, e.g. Lean, Six Sigma, Bench Marking, etc.

3. Core values and Organizational Culture, e.g. Focus on Customers, Focus on Employees, Continuous Improvements, etc..

The implication of suggesting QM to be considered as a management system containing three interdependent components is that understanding, analysing and diagnosing QM cannot be done without analysing all system components as well as their interrelationships.

\section{RESEARCH METHODS}

There have previously been several literature reviews on published QM and TQM related articles. For instance Ahire et al. (1995) conducted a literature review on published QM articles between 1970 and 1993, where they analyzed totally 226 articles. They used the MBNQA criteria as a framework for their analysis. Findings of the research were that most of the published QM related articles (72\%) were conceptual and case studies while slightly over $10 \%$ were empirical articles. Sila and Ebrahimpour (2002) also conducted a literature review based on published TQM research articles from 1989 to 2000. The research comprised TQM related articles which had adopted a survey methodology in order to study how TQM survey research had evolved over the 11 year period from 1989 to 2000. Recently Dereli et al (2011) did a literature analysis of papers published in the journal Total Quality Management \& Business Excellence from 1995 to 2008. Total 1132 papers were analysed in various criteria such as country origin, authors academic background, research methods, contents of keywords. Some conclusions from this study were:

- It has been recognized that TQM has started to receive an increasing amount of interest from the service industry.

- Methods used in $T Q M \& B E$ journal were not widely listed as keywords,

- However, the information of the speed of the improvement in TQM is still questionable. Therefore, without any doubt, it can be claimed that there is still a certain need for a further examination to measure the actual interest in TQM.

Lo and Chai (2012) did also a quantitative analysis of quality management literature published in Total Quality Management \& Business Excellence from 1996 to 2010. 
The main limitation of the last 2 studies is that they have been limited to research papers published in the journal of Total Quality Management \& Business Excellence. So far there is no updated literature research which covers contents and development of QM. Hence the present research will enhance this gap and carry out a long-range examination of published research articles within QM from 1987 to 2011.

There are several ways of conducting literature reviews such as a narrative literature review, a meta-analysis or a systematic review methodology (SRM) (Baumeister \& Learly, 1997; Tranfield et al., 2003). Based on our considerations on these methods we have adopted the systematic review methodology because the method has been widely implemented and also due to its systematic, scientific and transparent process of conducting literature reviews. SRM is considered to minimize biases and is suitable to produce evidence-based analyses. As Tranfield et al. (2003) suggested we have divided the review process into three stages of 1) planning, 2) conducting, 3) reporting.

Under the planning stage the main activities have been to identify review objectives and the review protocol which include clear review criteria and the process of inclusion and exclusion of published articles. We have chosen ABI/INFORM Complete periodical database as the search instrument. This database is one of the most comprehensive business and management databases on the market. It includes in-depth coverage of over 6,800 journals with more than $80 \%$ of the articles available in full text. In each search articles have been selected based on the document title with keywords. The subject-related keywords have been included in the search to prevent 'should-be-included articles' being missed from our research. Table 1 shows the list of the search keywords used.

Under the second stage of conducting the actual review process we firstly investigated the amount and the trend of research on Business Excellence (BE) and TQM. The time period starts from 1987, the year when the MBNQA was launched, and ends in 2011. During this 25-year period the number of articles published every year has been calculated and trend analyses have been performed. Following the investigations on TQM and BE, research papers on management tools and techniques as well as on quality culture/core values were also investigated. The procedures of the searches and the trend analyses related to those two elements were basically the same as in TQM and $\mathrm{BE}$.

In our research, the following five management techniques/tools were selected: 
Balanced Score Card (BSC); Enterprise Resource Planning (ERP); Just-in-Time (JIT)/

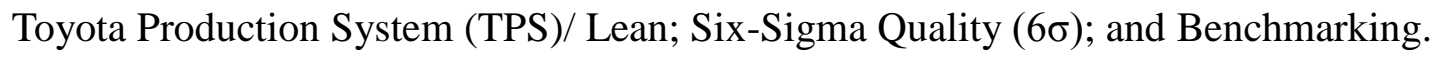

Finally five core values needed for building an organizational quality culture have been selected. The five values were selected because most quality literature considers those values as quality core values or key principles (Dahlgaard et al, 1992; Costin, 1994; Kanji, 1995; Dahlgaard-Park, 2011). The five TQM core values are: Leadership; customer focus; management-by-fact; people based management/ everybody's participation; and continuous improvement. In addition we also have searched literature on organizational culture, in order to investigate the possible impacts of TQM on the research of organizational culture. As is mentioned previously TQM is supposed to open new managerial paradigms represented by Organizational Culture Reform Movements (Shafritz \& Ott, 2001), or The Culture-Excellence approach (Burns, 2000).

Table 1 List of search keywords

\begin{tabular}{|c|c|}
\hline Elements & Search keywords \\
\hline Total quality management & Total quality management, TQM \\
\hline Business excellence & $\begin{array}{l}\text { Business excellence, BEM, BEF, National } \\
\text { Quality Award, NQA, MBNQA, Malcom } \\
\text { Baldrige, EFQM, EQA, Deming Prize }\end{array}$ \\
\hline BSC & Balance scorecard, BSC \\
\hline ERP & Enterprise resource planning, ERP \\
\hline JIT/TPS/Lean & $\begin{array}{l}\text { Just in time, JIT, Toyota production } \\
\text { system, TPS, lean }\end{array}$ \\
\hline Six-sigma & Six sigma, six-sigma, $6 \sigma, 6$ sigma \\
\hline $\begin{array}{l}\text { Organizational } \\
\text { Culture }\end{array}$ & Organizational Culture \\
\hline Leadership & Leadership \\
\hline $\begin{array}{l}\text { Delight the } \\
\text { customer }\end{array}$ & $\begin{array}{l}\text { Customer focus, customer involvement, } \\
\text { customer oriented }\end{array}$ \\
\hline $\begin{array}{l}\text { Management by } \\
\text { fact }\end{array}$ & $\begin{array}{l}\text { Management by fact, evidence based, } \\
\text { fact finding, fact based }\end{array}$ \\
\hline $\begin{array}{l}\text { People based } \\
\text { management }\end{array}$ & Teamwork \\
\hline $\begin{array}{l}\text { Continuous } \\
\text { improvement }\end{array}$ & Continuous improvement \\
\hline
\end{tabular}

The next and the final step was to make a systematic classification and analysis. The results of the review together with trend analysis as well as reflecting discussions will be presented in the following sections. 


\section{RESEARCH ON TQM AND BUSINESS EXCELLENCE}

Table 2 and 3 present the number of articles published under the subject of TQM and Business Excellence (BE), respectively. The number of articles published under the subject of TQM were 1954 articles which is significant more than the 343 articles published under the subject of BE during the same period. Most articles on TQM were published in 1995 (203 articles), while it was the year of 2002 where most BE articles were published (35 articles).

Table 2 Number of articles published in the subject of TQM (1987-2011)

\begin{tabular}{cccccccccc}
\hline Year & $\begin{array}{c}\text { \# of } \\
\text { articles }\end{array}$ & Year & $\begin{array}{c}\text { \# of } \\
\text { articles }\end{array}$ & Year & $\begin{array}{c}\text { \# of } \\
\text { articles }\end{array}$ & Year & $\begin{array}{c}\text { \# of } \\
\text { articles }\end{array}$ & Year & $\begin{array}{c}\text { \# of } \\
\text { articles }\end{array}$ \\
\hline 1987 & 1 & 1992 & 62 & 1997 & 120 & 2002 & 89 & 2007 & 43 \\
1988 & 3 & 1993 & 176 & 1998 & 113 & 2003 & 66 & 2008 & 47 \\
1989 & 1 & 1994 & 187 & 1999 & 85 & 2004 & 84 & 2009 & 44 \\
1990 & 20 & 1995 & 203 & 2000 & 78 & 2005 & 71 & 2010 & 56 \\
1991 & 43 & 1996 & 148 & 2001 & 91 & 2006 & 73 & 2011 & 50 \\
\hline
\end{tabular}

Table 3 Number of articles published in the subject of BE (1987-2011)

\begin{tabular}{cccccccccc}
\hline Year & $\begin{array}{c}\text { \# of } \\
\text { articles }\end{array}$ & Year & $\begin{array}{c}\text { \# of } \\
\text { articles }\end{array}$ & Year & $\begin{array}{c}\text { \# of } \\
\text { articles }\end{array}$ & Year & $\begin{array}{c}\text { \# of } \\
\text { articles }\end{array}$ & Year & $\begin{array}{c}\text { \# of } \\
\text { articles }\end{array}$ \\
\hline 1987 & 0 & 1992 & 3 & 1997 & 6 & 2002 & 35 & 2007 & 15 \\
1988 & 1 & 1993 & 5 & 1998 & 14 & 2003 & 32 & 2008 & 25 \\
1989 & 1 & 1994 & 2 & 1999 & 24 & 2004 & 24 & 2009 & 12 \\
1990 & 1 & 1995 & 8 & 2000 & 27 & 2005 & 21 & 2010 & 12 \\
1991 & 2 & 1996 & 6 & 2001 & 19 & 2006 & 19 & 2011 & 29 \\
\hline
\end{tabular}

Figure 1 shows the frequency chart for both subjects. It is apparent that research on TQM showed an uprising trend during 1987-1993, kept staying in the peak during 1994-1995, and then declined after 1995. Regarding the research on BE, it kept a steady-low trend during the 25-year period of time except that it showed a slow increasing trend in the periods of 1999-2004 and 2010-2011. 


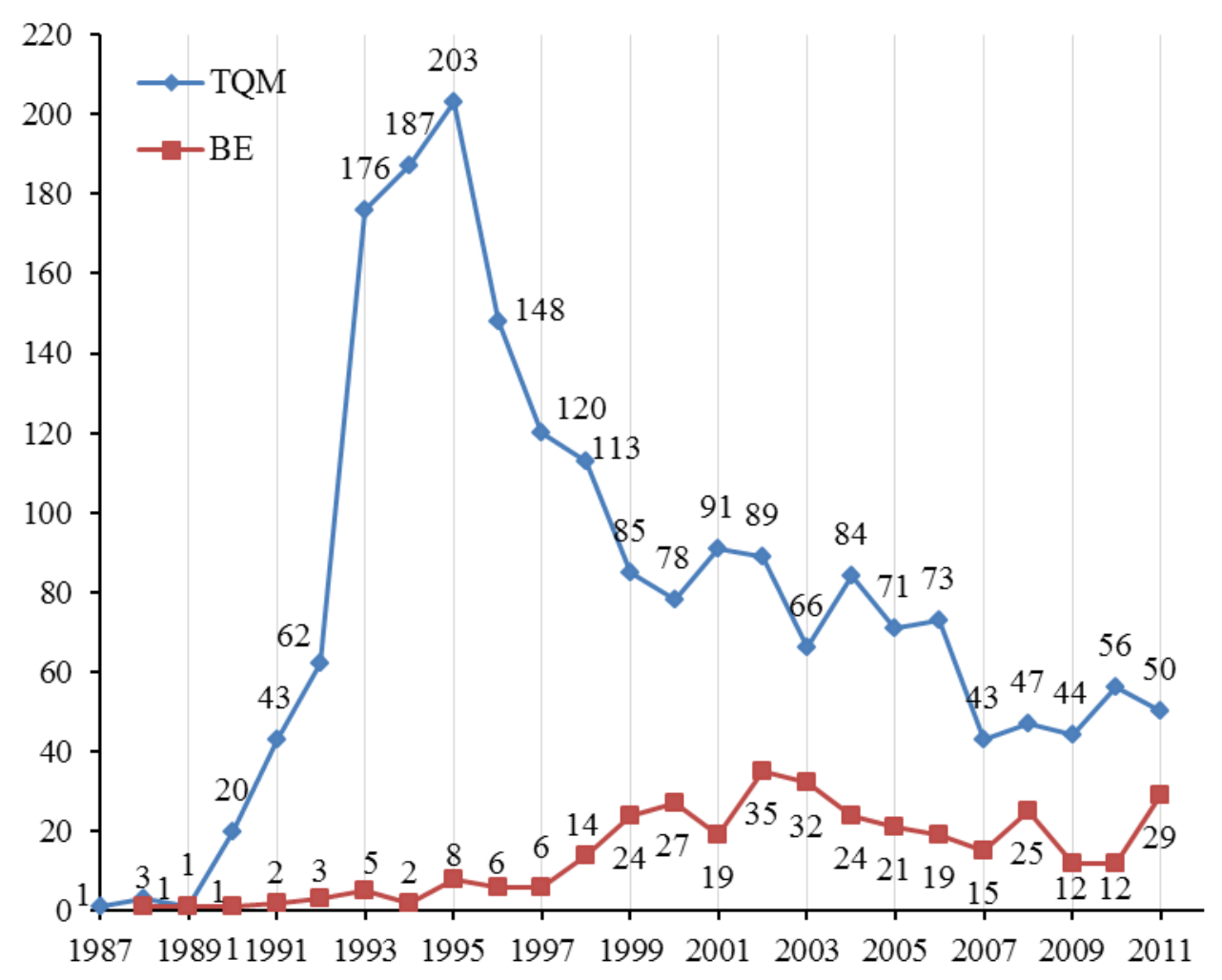

Figure 1: Frequency chart of the articles published under the subjects of TQM and BE (1987-2011)

The findings related to TQM from the last part of the $80^{\prime}$ and the $90^{\prime}$ are in accordance to the description given in the previous section. The 'almost sudden' rise of Japanese industrial and economic power forced American and other industrialized countries to search for the Japanese managerial recipe, and TQM was identified and considered to be the secret recipe. Thus it is not difficult to understand the high popularity of TQM research in this period.

Getting along with the successful achievement of TQM in Japan, Business Excellent Models (BEM) were developed in the western countries in the late 1980s and beginning of the 1990s, supported by national governments as the basis for award programs and as a management approach to promote quality. Hence BEM can be understood as an evolutional management approach of TQM because BEM were built on the same values.

However the coverage of managerial issues was extended to a further broadened perspective. Tan (2002) presented a comparative study of 16 NQA models used in a European context in an effort to build upon the key strengths of each model. The study revealed that except being indicative of the overall approach to TQM the 
models further emphasized the criteria of 'people management' and 'impact on society', which cover the social as well as the economic responsibilities of organizations. Based on the criteria and its weights the US MBNQA model was found to have an increasing emphasis on 'leadership' and 'results' criteria.

Although the total number of published research papers on BE does not show a significant increase the number of countries which have established a national business excellence framework (BEF) has constantly been increasing during the last decade. Recent research documents that as of 2011 there were approximately 100 national business excellence frameworks being used across the world (Talwar, 2011; Mann et al., 2011).

According to the above argumentation the trends in the research on both subjects shown in Figure 1 do follow the history of TQM and BE. Figure 1 indicates that there is a 5-10 years time lag on the research of TQM and BE. However, it is further documented that the research on BE didn't show a significant increase when the research on TQM started to decline in the late 1990s. This implies that BE didn't become a substitute management approach of TQM, as it might be expected. This phenomenon will be further discussed in Section 6 .

\section{RESEARCH ON QUALITY MANAGEMENT TOOLS AND TECHNIQUES}

Table 4 presents the number of articles on each of the five management techniques/tools published during 1987-2011. For each of the five management techniques/tools the amount of research in the recent decade (2002-2011) is significantly higher than that in the first decade (1987-1996). It is also interesting to see that for each of the five management techniques/tools the total number of articles were significantly higher than the number of articles published on the subject of BE during the same period of time. The highest number of articles published was related to the subjects of JIT/TPS/Lean (2206 articles), which is higher than the number of articles on TQM (1954 articles).

Table 4 Number of articles published on the subject of five management tools/techniques (1987-2011)

\begin{tabular}{cccccc}
\hline Year & BSC & ERP & JIT/TPS/Lean & Benchmarking & 6 \\
\hline 1987 & 0 & 0 & 42 & 3 & 0 \\
1988 & 0 & 0 & 40 & 0 & 0 \\
1989 & 0 & 0 & 42 & 8 & 0 \\
1990 & 0 & 2 & 60 & 3 & 0 \\
1991 & 0 & 0 & 57 & 2 & 0 \\
\hline
\end{tabular}




\begin{tabular}{cccccc}
\hline 1992 & 0 & 0 & 63 & 24 & 2 \\
1993 & 0 & 1 & 90 & 48 & 1 \\
1994 & 2 & 1 & 91 & 42 & 5 \\
1995 & 1 & 2 & 136 & 48 & 1 \\
1996 & 8 & 2 & 85 & 53 & 0 \\
1997 & 13 & 4 & 64 & 50 & 0 \\
1998 & 14 & 11 & 61 & 76 & 8 \\
1999 & 7 & 19 & 54 & 65 & 7 \\
2000 & 19 & 38 & 64 & 77 & 39 \\
2001 & 21 & 42 & 69 & 77 & 38 \\
2002 & 28 & 46 & 72 & 64 & 67 \\
2003 & 32 & 66 & 91 & 72 & 82 \\
2004 & 42 & 76 & 100 & 77 & 96 \\
2005 & 38 & 93 & 135 & 84 & 62 \\
2006 & 43 & 92 & 111 & 89 & 86 \\
2007 & 36 & 75 & 112 & 81 & 79 \\
2008 & 44 & 94 & 128 & 83 & 69 \\
2009 & 29 & 79 & 133 & 86 & 65 \\
2010 & 49 & 69 & 195 & 66 & 91 \\
2011 & 45 & 83 & 111 & 59 & 58 \\
Total & $\mathbf{4 7 1}$ & $\mathbf{8 9 5}$ & $\mathbf{2 2 0 6}$ & $\mathbf{1 3 3 7}$ & $\mathbf{8 5 6}$ \\
\hline
\end{tabular}

Figure 2 shows the frequency chart for the number of articles published in the subject of the five management techniques/tools and figure 3 shows trend analyses. All of the five management techniques/tools show an increasing trend during the past 25 years but the trend curves have different shapes. It is found that the trend curves related to ERP and JIT/TPS/Lean are concave which indicates that the amount of research on these subjects are steeply increasing over time. The trend curves shown on six-sigma and benchmarking are convex which indicate that the increasing rate are declining in spite of they still have an increasing trend. The trend curve of BSC is close to linear which indicates that the increasing rate is roughly constant. 


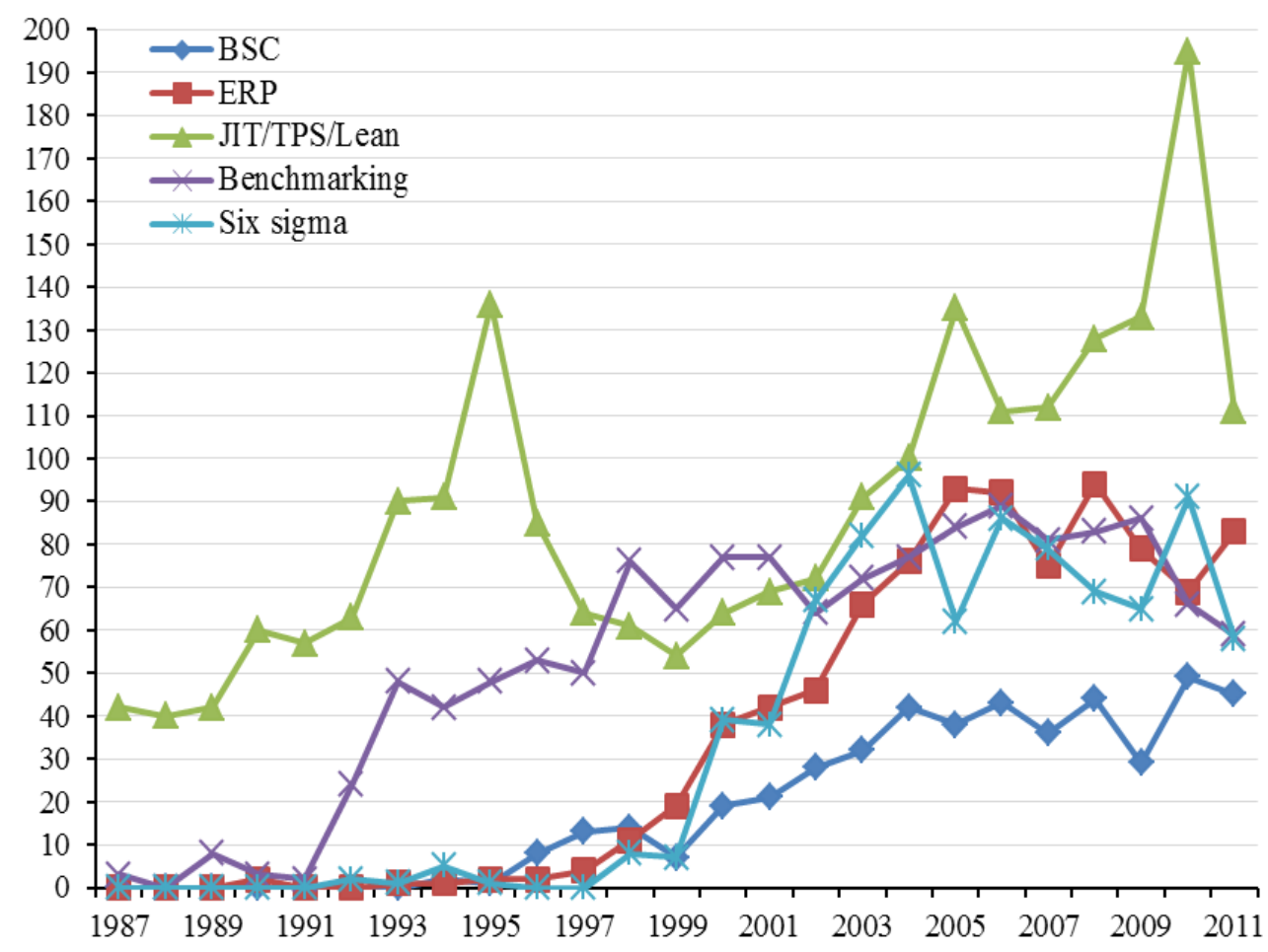

Figure 2 Frequency chart for number of articles published in the subject of five management tools/techniques (1987-2011)

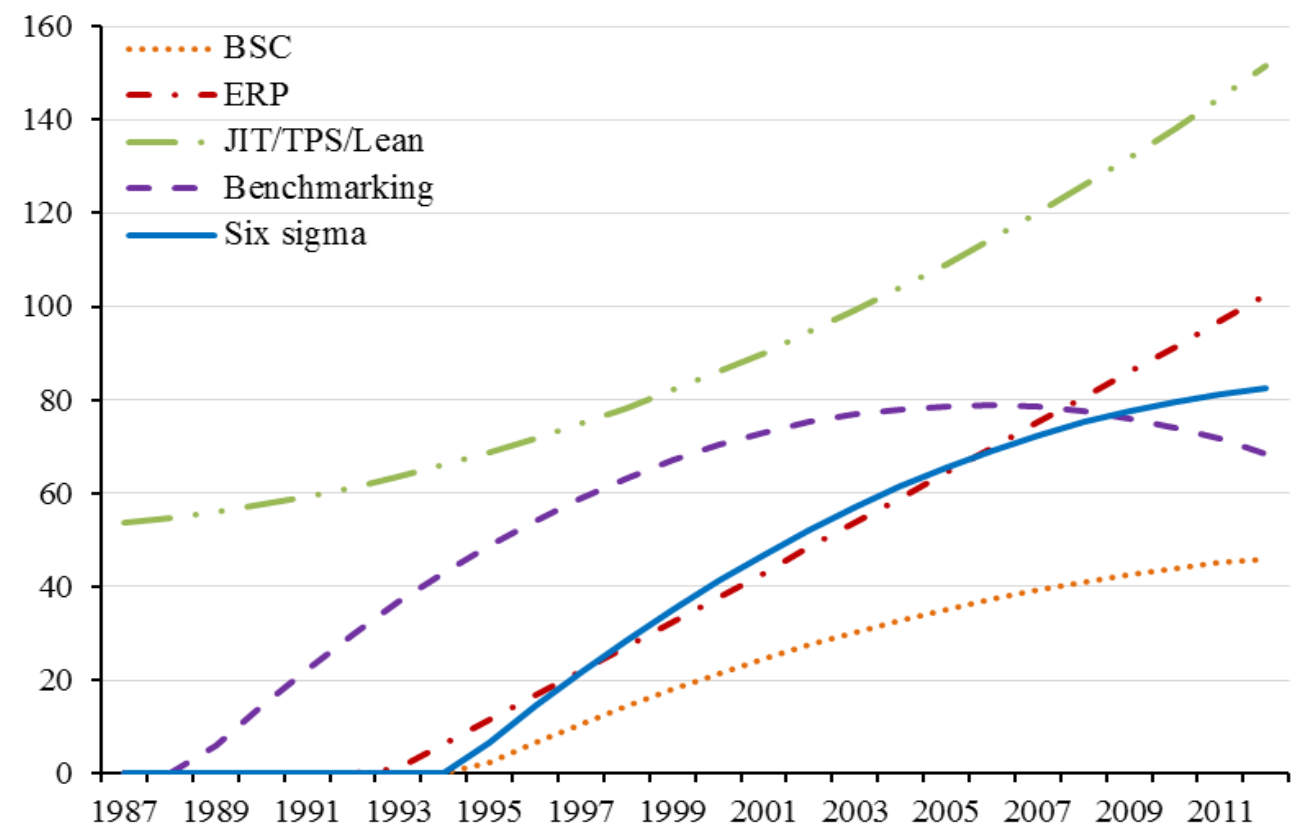

Figure 3 Trend analyses for the articles published in the subject of the five management techniques/tools (1987-2011)

Based on the information shown in the above tables and figures, the implications are 
further investigated. First of all, the five management techniques/tools seem more popular than Business Excellence Models (BEM). It may be further implied that there are more successful adoptions of the five management techniques/tools than that of BEM. Secondly, each management technique/tool has its own specific managerial function related to Deming's management cycle PDCA (Plan-Do-Check-Act) or PDSA (Plan-Do-Study-Act). Chen \& Jang (2011) proposed that BSC serves as 'plan' function, ERP/JIT/TPS/Lean serve as 'do' function, BEM serves as 'check' and six-sigma and benchmarking serve as 'action' functions. In terms of the managerial functions of PDCA it was found that the operation function (Do), including ERP and JIT/TPS/Lean, shows the largest amount of research $(895+2206=3101$ articles $)$. The Action function, including six-sigma and benchmarking, has the second largest amount of research $(856+1337=2193$ articles). The Plan function (BSC) and the Check function (BE) are at the third (471 articles) and the fourth places (343 articles). More on the PDCA functions will be discussed below.

In terms of the amount of research on these four managerial functions, it is interesting to find that the two functions 'do' and 'action' $(3101+2193=5294$ articles), have much more research attention than that of the other two functions, 'plan' and 'check' $(471+343=814$ articles $)$. The shapes of their trend curves also reflect this phenomenon.

If 'do' and 'action' represent 'executing the action strategies' and 'plan' and 'check' represent 'exploring the governing variables' for double-loop learning, the findings indicate that most organizations are practicing single-loop learning (adaptive learning) rather than double-loop and triple-loop learning which is generative learning. This means that organizations mostly focus on 'how to do' but not paying much attention on 'why to do' (Dahlgaard-Park, 2006-b). Thus, the development of easy-to-use management tools for the 'plan' and 'check' functions seems to be an important research topic for the future.

\section{RESEARCH ON ORGANIZATIONAL CULTURE}

Table 5 presents the number of articles on the subject of organizational culture published during 1987-2011. The total number of articles published on this subject was 873 . Figure 4 shows the frequency chart and the trend analyses. It is found that the trend curve is concave which indicates that the amount of research on this subject is increasing over time and the speed of increase is increasing as well. The number of articles published per year during 1987-1996 is in the range of 10-30 growing to 
30-60 articles per year during 1997-2006, and becomes over 60 articles per year after the year 2007. The number of articles published in the year 2011 (95 articles) is about eight times of the number in the year 1987 (12 articles). The trend shows clearly that organizational culture as a research subject has become more and more important over time.

Table 5 Number of articles published in the subject of organizational culture

\begin{tabular}{cccccccccc}
\hline Year & $\begin{array}{c}\text { \# of } \\
\text { articles }\end{array}$ & Year & $\begin{array}{c}\text { \# of } \\
\text { articles }\end{array}$ & Year & $\begin{array}{c}\text { \# of } \\
\text { articles }\end{array}$ & Year & $\begin{array}{c}\text { \# of } \\
\text { articles }\end{array}$ & Year & $\begin{array}{c}\text { \# of } \\
\text { articles }\end{array}$ \\
\hline 1987 & 12 & 1992 & 24 & 1997 & 23 & 2002 & 25 & 2007 & 69 \\
1988 & 15 & 1993 & 25 & 1998 & 34 & 2003 & 48 & 2008 & 65 \\
1989 & 12 & 1994 & 27 & 1999 & 36 & 2004 & 55 & 2009 & 68 \\
1990 & 14 & 1995 & 33 & 2000 & 35 & 2005 & 42 & 2010 & 94 \\
1991 & 15 & 1996 & 32 & 2001 & 35 & 2006 & 57 & 2011 & 95 \\
\hline
\end{tabular}

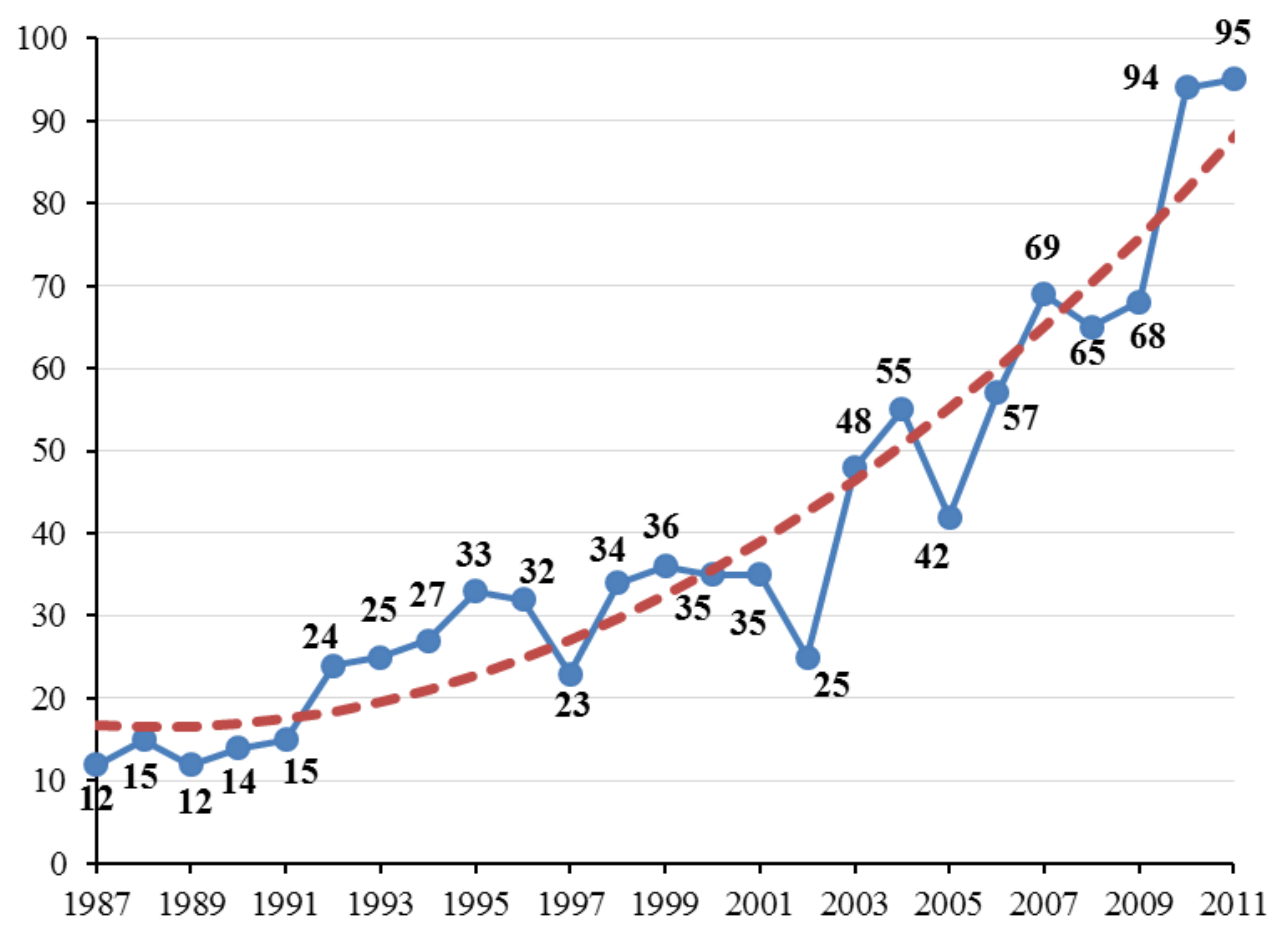

Figure 4 Frequency chart and trend analysis for number of articles published in the subject of organizational culture (1987-2011)

Table 6 presents the number of articles on the subject of leadership published during 1987-2011. The total number of articles published on leadership was 7083 articles. This is the largest amount of research among all article subjects investigated. Figure 5 shows the frequency chart and the trend analyses on the subject. The trend curve is concave which is the same as the subject of organizational culture. The trend curve is increasing over time and keeps increasing by an increasing speed. The number of articles published per year during 1987-1996 is under 200, and there were 200-500 
articles per year during 1997-2006. The number passed 500 articles per year after 2007, and the number of articles published in the year of 2011 (673 articles) has increased by a factor of about 11.5 compared with 1987 (59 articles). The trend shows that research on leadership has become more and more important over time.

Table 6 Number of articles published in the subject of leadership (1987-2011)

\begin{tabular}{cccccccccc}
\hline Year & $\begin{array}{c}\text { \# of } \\
\text { article }\end{array}$ & Year & $\begin{array}{c}\text { \# of } \\
\text { article }\end{array}$ & Year & $\begin{array}{c}\text { \# of } \\
\text { article }\end{array}$ & Year & $\begin{array}{c}\text { \# of } \\
\text { article }\end{array}$ & Year & $\begin{array}{c}\text { \# of } \\
\text { article }\end{array}$ \\
\hline 1987 & 59 & 1992 & 155 & 1997 & 210 & 2002 & 356 & 2007 & 529 \\
1988 & 70 & 1993 & 197 & 1998 & 254 & 2003 & 402 & 2008 & 538 \\
1989 & 97 & 1994 & 188 & 1999 & 294 & 2004 & 463 & 2009 & 559 \\
1990 & 130 & 1995 & 186 & 2000 & 269 & 2005 & 530 & 2010 & 674 \\
1991 & 123 & 1996 & 206 & 2001 & 295 & 2006 & 457 & 2011 & 673 \\
\hline
\end{tabular}

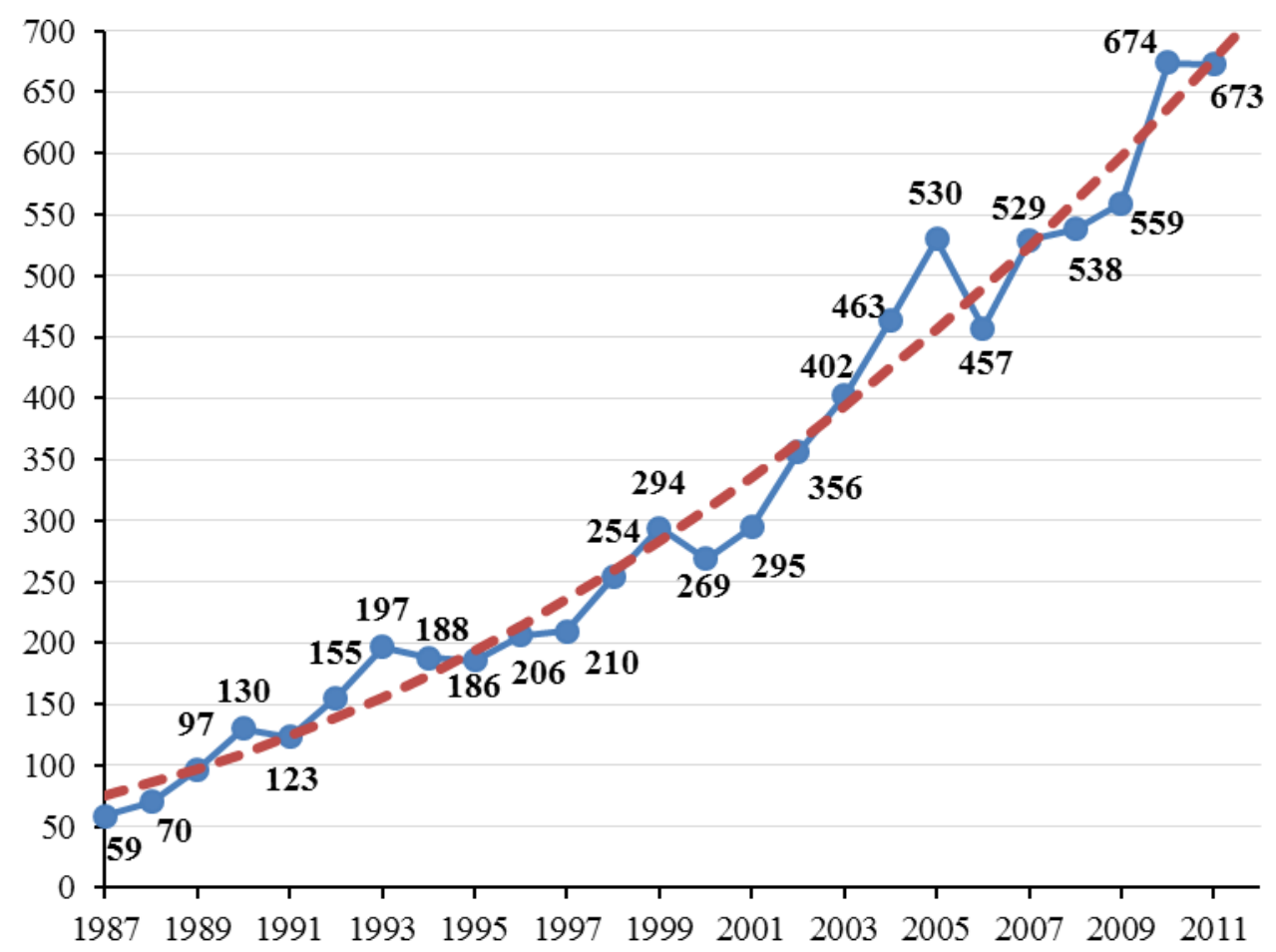

Figure 5 Frequency chart and trend analysis for number of articles published in the subject of leadership (1987-2011)

Table 7 presents the number of articles published on the subjects of quality core values/ principles. The subject of people based management/everybody's participation (683 articles) has the largest total number of research articles among the four core values/principles. Management by fact is in the second place (566 articles), Continuous improvement the third place (402 articles), and delight the customer/ focus on the customer shows the least total number of research articles (182 articles). Comparing to all subjects investigated in this paper it is found that the amount of 
research on these four core values/principles belong to the less researched area of QM.

Table 7 Number of articles published in the subject of four core values /principles (1987-2011)

\begin{tabular}{ccccc}
\hline Year & $\begin{array}{c}\text { Delight the } \\
\text { customer }\end{array}$ & $\begin{array}{c}\text { Management by } \\
\text { fact }\end{array}$ & $\begin{array}{c}\text { People based } \\
\text { management }\end{array}$ & $\begin{array}{c}\text { Continuous } \\
\text { improvement }\end{array}$ \\
\hline 1987 & 3 & 0 & 3 & 0 \\
1988 & 3 & 0 & 6 & 0 \\
1989 & 1 & 0 & 15 & 2 \\
1990 & 1 & 0 & 17 & 3 \\
1991 & 3 & 1 & 20 & 12 \\
1992 & 6 & 1 & 22 & 16 \\
1993 & 4 & 0 & 33 & 15 \\
1994 & 4 & 2 & 35 & 20 \\
1995 & 10 & 4 & 40 & 23 \\
1996 & 5 & 1 & 43 & 19 \\
1997 & 7 & 11 & 29 & 27 \\
1998 & 3 & 9 & 37 & 13 \\
1999 & 9 & 15 & 34 & 33 \\
2000 & 11 & 13 & 29 & 28 \\
2001 & 9 & 14 & 24 & 16 \\
2002 & 9 & 21 & 31 & 30 \\
2003 & 11 & 29 & 34 & 12 \\
2004 & 12 & 44 & 22 & 16 \\
2005 & 12 & 59 & 37 & 18 \\
2006 & 8 & 65 & 30 & 13 \\
2007 & 9 & 53 & 26 & 16 \\
2008 & 9 & 60 & 40 & 14 \\
2009 & 12 & 49 & 29 & 23 \\
2010 & 8 & 64 & 23 & $\mathbf{4 0 2}$ \\
2011 & 13 & 51 & $\mathbf{6 8 3}$ & \\
Total & $\mathbf{1 8 2}$ & $\mathbf{5 6 6}$ & & 12 \\
\hline & & & 0 & 24 \\
\hline
\end{tabular}

Figure 6 shows the frequency chart for the number of articles published on the subjects of the four core values/principles while figure 7 shows the trend analyses. It is found that the trend curves shown have different shapes. First of all, the trend curves shown on 'management by fact' are concave which indicate that the amount of research on this subject is steeply increasing over time. The trend curves shown on delight the customer/focus on the customer keeps slow and constant increasing but the total number of articles is the least among the four groups. The trend curves shown on people based management and continuous improvements are convex and it deserves to pay attention that the amount of research on those two subjects has been decreasing during the last decade. The total number of research articles published on the subject of people based management/everybody's participation was the largest among the 
four groups.

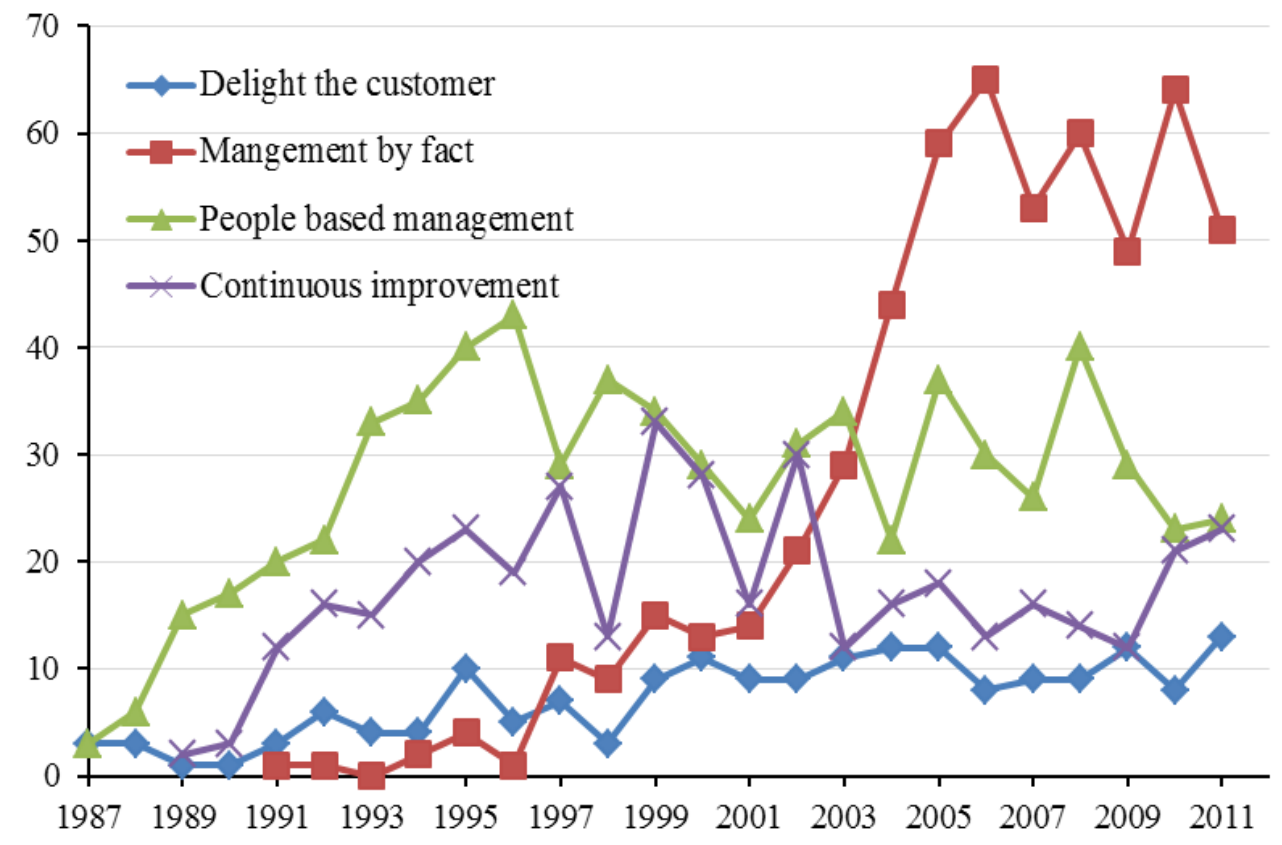

Figure 6 Frequency chart for number of articles published in the subject of four core values/principles (1987-2011)

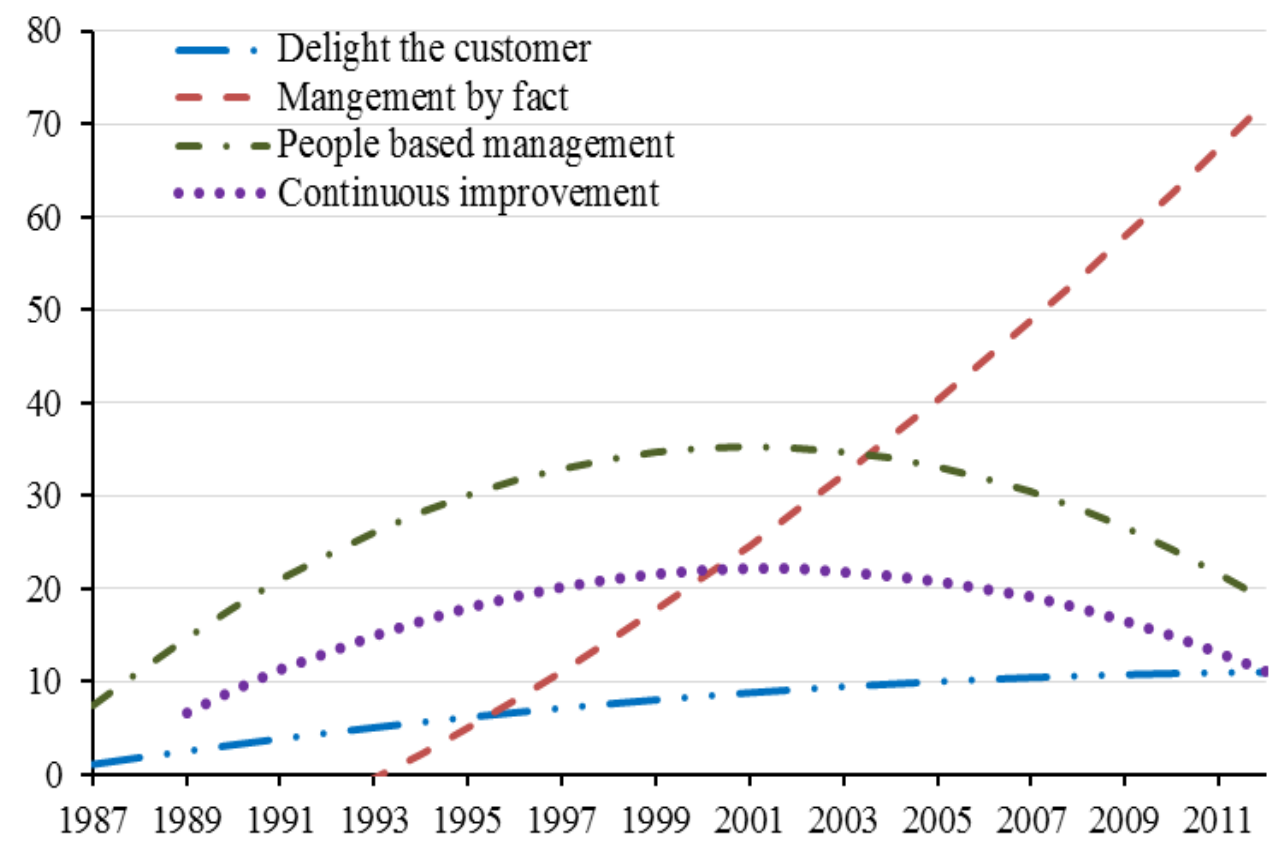

Figure 7 Trend analyses for the articles published in the subject of the four core values/principles (1987-2011)

Based on the information shown in the above tables and figures the implications were further investigated. First of all, leadership is often perceived as the most important element for an organization for pursuing business excellence. The amount of research 
on this subject is the largest among the research subjects investigated and it keeps steeply increasing over time. Secondly, it is found that organizational culture has caught an increased attention during the recent decade. Advocating challenging work, open communication, trust, innovation, and cohesion among employees are all essential attributes in defining a supportive culture. Dahlgaard \& Dahlgaard-Park (2006) argued that changing a corporate culture from passive and defensive to a proactive and open culture among all employees is critical for increasing customer satisfaction and continuous improvement. A successful implementation of TQM and $\mathrm{BE}$ depends on the prevailing culture of the organization (Green, 2012).

In terms of the above research findings it was found that organizational culture is becoming more and more important in the pursuit of business excellence. But on the other hand, it deserves to pay attention that the total number of research articles on this subject is still less than TQM and some of the management techniques/tools. It seems that the four TQM core values/principles and their linkages to quality culture have not caught enough research attention. In particular, even if delight the customer is the most important factor for having success with Business Excellence it was found that the research on this subject is much less than that on the other subjects investigated. This implies that there are great research opportunities to pay more efforts on those elements.

\section{DISCUSSION \& CONCLUSIONS}

TQM and Business Excellence Models (BEM) have become popular and been widely used in practice for about 25 years. However, in light of the research results shown in Section 3, a quick conclusion by people without a profound knowledge about the evolution of QM may be that TQM \& BEM seems now to be in the middle of a crisis. Others may complement by saying that TQM \& BEM belong to those temporal management fashions or fads which have been popular for a while and now they are ultimately on the way to 'disappear' from people's memories and minds. Before we join to such a quick conclusion, we need to consider further on the phenomenon of management fashion.

Abrahamson (1991) provided four explanations when certain management techniques fall out of favor and fade over time, with a view that a management technique/topic is in fashion if it is both popular and research is carried out around it. On the other hand a management technique/topic is viewed unfashionable when it is not popular and when there is no research around it. According to Abrahamson (1991), firstly the 
decline of certain management techniques may be a result of being not used by organizations because the management techniques are specifically practitioner-oriented. Secondly powerful institutions can force to adopt certain management techniques for institutional control as for instance US government war-labor boards forced the dissemination of human resources practices under the Second World War. Thirdly influential 'fashion setters' represented by business mass media, consultants and business schools etc. can influence organizations to adopt and imitate certain management techniques. The last explanation is when organizations adopt the same management trends or techniques as their peer organizations as a way of legitimizing.

Seen from our findings, it is quite obvious that the total number of research articles on TQM and BE has been declining over time. For instance, the total number of articles was $211(203+8=211$ articles $)$ in the year of 1995 , while it was only $68(56+12=68$ articles) and $79(50+29=79$ articles $)$ in the years of 2010 and 2011 . This is only about one third of the research articles being published in 2011 compared to 1995. If we observe these numbers alone and ignore the interrelationships to other criteria e.g. quality tools/techniques, organizational culture, quality core values we may conclude that TQM \& BE may belong to management fads and it is now on its way of fading out.

However, if we consider in relation to the evolution of QM and hence the interrelationship between those criteria then we will also understand that data on the number of articles published on TQM \& BE is too narrow to conclude as above. Because TQM and BEM comprise multiple numbers of tools and techniques as well as culture and core values/ principles then we should also collect and analyze data about these areas before we come up with a quick conclusion about the current state and expected future directions. Such data were presented in Sections 4 and 5.

The results showed that the total number of articles under the subject of TQM has been decreasing since 1995 after having reached its peak. On the other hand, papers focusing on techniques and tools within the quality management framework, in terms of Lean, JIT/TPS, Benchmarking, Six Sigma have been increasing. Papers focusing on the core values/principles needed to build a quality culture in terms of leadership, people based management, continuous improvement, management based on facts, and customer focus have been slightly increasing during the last decade. These findings indicate that QM is now in a more mature stage where focuses have shifted from an initial focus on TQM to the tools, techniques and core values which are needed to 
implement QM and build a quality and business excellence culture.

When relating QM to the four explanations of management fashion we observe a contradiction. While several explanations are well matching to TQM and BE, we can't say that the QM is fading out. Although researchers are not necessarily using the terms of TQM or BE, research on $\mathrm{QM}$ in general seems to be increasing overall. When considering all published papers under the terms of Lean, JIT/TPS, Benchmarking, Six Sigma and factors related to building organizational quality culture, we can conclude that the character of research within QM are now at a more mature and advanced level.

The observation above is also corresponding to previous identified quality evolution trends (Dahlgaard Park, 1999). The two main evolution patterns identified within QM were simultaneously a horizontal and a vertical movement. The horizontal movement refers to the broadening mechanisms where QM broadens its conceptual framework embracing tools/techniques, core values as well as implication areas. From the initial implication of QM mainly for the manufacturing industry QM has been spread to all kind of industries as well as the public sector. Health care, education, public administration, and the tourism \& hospitality sector among many are all eager to adopt QM. Accordingly we have seen a widening from quality of products and processes to quality of services (embracing all kinds of services), quality of life and quality of the environment. Hence the challenges have been continuously to adjust and modify the QM framework and at the same time to continuously develop better tools and techniques in order to fit with the needs of these new service and knowledge intensified organizations. One of the critical challenges in the future can be for instance to develop better tools and techniques which can be adopted for realization of value co-creation between customers and service providers in service contexts. Accordingly developing a way to better involve and empower customers in all processes will be a critical issue.

Another identified evolution pattern - the vertical movement (Dahlgaard Park, 1999) is concerned with the deepening mechanism, where practitioners and researchers continuously achieve deeper meanings on key concepts within QM. The vertical movement is intertwined with the horizontal movement where actors get a more comprehensive and deeper meaning on quality as well as on organizations. One example of the vertical movement is the constantly redefined meanings attached to the concept of quality from being defined as the degree of conformance to specifications, to fitness for use, zero defects and to exceed customers' needs. It is difficult to predict 
how the definition of quality will evolve in this rapidly changing global world which becomes increasingly more virtual, interactional, experience oriented, ubiquitous and borderless. Probably the future definition of quality will embrace more interactional and experiencing aspects. Another example is related to the increasing interest on organizational culture and core values. Most of the key components of organizational culture have intangible characters in terms of core values, norms and traditions. To work with these intangible factors are not straightforward and requires more insights than tangible factors.

The findings in this article have also identified an important research issue in respect to how BEM can be well-integrated with existing management systems when introduced into an organization. The finding is that, in terms of Deming's PDCA/ PDSA management cycle, the research on the functions of 'plan' and 'check/ study' is much less than the other two functions, 'do' and 'action'. This finding may indicate that most of organizations are practicing single-loop learning rather than double-loop learning. Thus, the authors argue that to develop easy-to-use management tools for the 'plan' and 'check' function should be an important research issue in the near future.

The last finding, in terms of the results revealed in Section 5, indicates that the subject of organizational culture are becoming more and more important for organizations in the pursuit of quality and excellence. In relation to this finding, the authors argue that it deserves to pay more research attention on the core values related to building a quality culture such as customers centrism (focus on customers' problems, needs and expectations), continuous improvement and everybody's participation because research on those subjects seem not to match the importance as claimed by people in practical situations.

\section{REFERENCES}

Abrahamson, E. (1991). Managerial fads and fashions: The diffusion and rejection of innovations, Academy of Management Review, 16 (3): 586-612.

Abrahamson, E. (1996). Managerial fashion, Academy of Management Review, 21(1):254-285.

Ahire, S.L., Landeros, R., Golhar, D.Y. (1995). Total Quality Management: a literature review and an agenda for future research, Production and Operations Management, 4 (3): 277-306. 
Baumeister, R. F., \& Leary, M. R. (1997). Writing narrative literature reviews, Review of General Psychology, 1 (3): 311-320

Bergman, B. \& Klefsjö, B. (1994) Quality from customer needs to customer satisfaction, Lund: Student literature.

Burns, B. (2004) Managing Change, London: Prentice Hall

Chen, C.K. and Jang, J.Y. (2011). FACT: a comprehensive business excellence Model, in Proceedings QMOD Conference on Quality and Service Sciences 2011, San Sebastian, Spain, Universidad de Navarra, 413-437.

Costin, H. (1994). Readings in Total Quality Management. Dryden Press, Orlando.

Dahlgaard, J.J. \& Kristensen, K. (1992). The Quality Journey (in Danish, later published on Carfax, London in 1994 and Productivity Press, India in 1995 with G. Kanji as the third author), Centrum, Aarhus, Denmark.

Dahlgaard, J.J. \& Dahlgaard-Park, S.M. (2006). Lean production, six sigma quality, TQM and company culture, The TQM Magazine, 18 (3): 263-281.

Dahlgaard Park, S.M. (1999). The evolution patterns of quality management: some reflections on the quality movement, Total Quality Management, 10 (4\&5): 473-480.

Dahlgaard-Park, S. M. (2006-a), (Editorial). Transformation and consistency in the Quality Movement, The TQM Magazine, 18 (3): 213-215.

Dahlgaard-Park, S.M. (2006-b). Learning from East to West and West to East, The TQM Magazine, 18 (3): 216-337.

Dahlgaard-Park, S.M. (2011). The Quality Movement - where are you gong?, Total Quality Management \& Business Excellence, 22 (5): 493-516.

Dahlgaard-Park, S.M. (2012). Core values - the entrance to human satisfaction \& commitment, Total Quality Management \& Business Excellence, 23 (2): 125-140.

Dean, J. W. \& Bowen, D. E. (1994) Management Theory and Total Quality: Improving Research and Practce through Theory Developemnt, The Academy of Management Review, Vol. 19 (3): 392-418

Deming, W. E. (1993). The New Economics - for Industry, Government, Education, Massachusetts Institute of Technology, Center for Advanced Engineering Study, Cambridge, MA, USA

Dereli, T, Durmusoglu, A., Delibas, D. \& Avlanmaz, N. (2011). An analysis of the papers published in Total Quality Management \& Business Excellence from 1995 through 2008, Total Quality Management \& Business Excellence, 22 (3): 373-386.

Green, T. (2012). TQM and organisational culture: How do they link?, Total Quality Management \& Businessss Excellence, Dahlgaard-Park, S.M. (ed.) Special 
issue on The Human Dimension and Organizational Performance 23 (2): 141-157.

Ismail S. \& Ebrahimpour, M. (2002). An investigation of the Total Quality Management survey based research published between 1989 and 2000: a literature review, International Journal of Quality and Reliability Management, 19 (7): 902-970

Hellsten, U. \& Klefsjö, B. (2000). TQM as a management system consisting of values, techniques and tools, The TQM Magazine, 12 (4): 238-244.

Kanji, G.K. (1995). Total Quality Management: Proceedings of the First World Congress, Chapman \& Hall, London.

Lo, Q.Q. \& Chai, K.H. (2012). Quantitative analysis of quality management literature published in Total Quality Management \& Business Excellence (1996-2010), Total Quality Management \& Businessss Excellence, 23 (6): 629-651.

Mann, R., Adebanjo, D., Laosirihongthong, T. and Punnakitikashem, P. (2011). Awareness and impact of business excellence in Asia, Total Quality Management \& Businessss Excellence, 22 (11): 1237-1258.

Oakland, J. (1999). Total Quality Management. Butterworth-Heinemann.

Scarbrough, H., Robertson, M., and Swan, J. (2005. Professional media and management fashin: the case of knowledge management. Scandinavian Journal of Management, 21:197-208.

Schein, E.H. (1993). On dialogue, culture, and organizational learning, Organizational Dynamics, 22 (2): 40-51.

Shafritz, Jay M. \& Ott, J. Steven (2001) Classics of Organization Theory. London: Harcourt College Publishers

Sila, I. \& Ebrahimpour, M. (2002). An investigation of the total quality management survey based research published between 1989 and 2000. International Journal of Quality and Reliability Management, 19(7), 902-970.

Tan, K.C. (2002), A comparative study of 16 national quality awards, The TQM Magazine, 14 (3): 165-171.

Talwar, B. (2011) Business excellence models and the path ahead. The TQM Magazine, 23 (1):21-35.

Tranfield, D., Denyer, D., \& Smart, P. (2003). Towards a methodology for developing evidence-informed management knowledge by means of systematic review, British Journal of Management, 14 (3): 207-222.

Van Der Wiele, Williams, A.R.T. \& Dale, B.G. (2000). Total Quality Management: is it a fad, fashion, or fit? ASQ Quality Management Journal, 7 (2): 65-79.

Wilkinson, A. \& Wilmott, H. (1996), Making Quality Critical. London: Routledge.

Wruck, K.H., Jensen, M.C. (1994). Science, Specific Knowledge and Total Quality 
Management , Journal of Accounting and Economics, 18, 247 - 287. 